Accepted refereed manuscript of: Reid L, McKee K \& Crawford J (2015) Exploring the stigmatization of energy efficiency in the UK: An emerging research agenda. Energy Research \& Social Science, 10, pp. 141-149. DOI: https://doi.org/10.1016/j.erss.2015.07.010

(C) 2015, Elsevier. Licensed under the Creative Commons Attribution-NonCommercial-NoDerivatives 4.0 International http://creativecommons.org/licenses/by-nc-nd/4.0/

\title{
Exploring the Stigmatization of Energy Efficiency in the United Kingdom: an emerging research agenda
}

Energy efficiency technology is widely accepted as a positive step to improve the comfort of homes whilst simultaneously reducing harmful carbon emissions. There is a convincing case that more widespread adoption of energy efficiency technology is required, yet paradoxically, the identification of households as being in need of assistance to do so, may, we argue, be stigmatizing. Recent literature has begun to explore the role of stigma in domestic energy-saving practices but such scholarship is restricted beyond a few studies. In this exploratory paper we respond to calls for social scientists to engage with energy research, and redress this neglect by outlining the nature of the relationship between energy efficiency and stigma. We also seek to develop an emerging research agenda, which draws theoretical influence from Sociology and Housing Studies.

Keywords: Energy efficiency; Bourdieu; consumption; stigma; housing policy; UK; Scotland

\section{Introduction}

The environmental impact of the UK housing system has for many years been the subject of attention (Lovell 2004, Priemus 2005), scrutiny having intensified in the 'new realism of climate change' (While et al., 2010: 82). The legacy of old and hard-to-heat homes has led to the development of an energy and thermally inefficient housing stock (HM Government 2010, Scottish Housing Condition Survey 2013). One solution to this has been the development of legislation and regulation for building fabrics, the Code for Sustainable Homes being one such example (BREEAM 2010). Another has been the introduction of policies for efficiency improvements, targeted at households and homes deemed in need of improvement. In the context of this paper, we are interested in both the technologies and practices related to energy efficiency, that is, a practice or technology which saves energy because it uses less energy to provide the same service. For example, using a compact fluorescent bulb instead of a traditional incandescent bulb, or replacing a single pane of glass in a window with a double or triple glazed unit. Practices are those activities undertaken to improve efficiency, for instance, the installation or use of these technologies.

Yet, the effect of energy efficient policies, and specifically how they may (re)stigmatise householders in receipt of new energy efficiency improvements, has been a neglected area of research. Indeed, the relationship between stigma and energy efficiency is an area where social science could make considerable new contributions to energy research building on existing contributions around fuel poverty (Bruner et al., 2012, Middlemiss and Gillard 2015, Sovacool 2014, Walker and Day 2012) and changing patterns of demand (Lutzenhiser 2014, Walker 2014, Wilhite et al., 2000). In so doing, we hope to highlight that social pressures may prevent the effective implementation of energy efficiency strategies in the housing sector in a way that technical approaches to energy efficiency may be unable to overcome, since they do not deal with what are fundamentally social concerns. Our paper thus contributes to this journal's engagement in ongoing debates about the 'energy efficiency gap' (Wilson et al., 2015, Pelenur and Cruickshank 2012, Dowson et al., 2012), and in particular attempts to emphasise the social nature of energy use (Shove and Walker, 2014, Sovacool 2014, Wilson et al., 2015). The relationship between stigma and energy efficiency is particularly underdeveloped when one considers the attention dedicated to explaining reasons for the low uptake of efficiency improvements. As has been documented, evidence about the installation of efficiency measures is mixed and contingent on the sociodemographic characteristics of households and the type of technology installed (Dowson et al., 2012, Hamilton, et al., 2014, Pelenur and Cruickshank 2012). Common explanations for installation rates relate to finances, information and decision making, yet these have been critiqued for representing only a narrow set of explanations missing the wider, socially embedded nature of everyday practices (Wilson et al., 2015). Stigma, one potentially important element has thus been neglected, yet there is much to be gained from making connections to the existing scholarship on stigma in social science more broadly. This paper proposes two different, yet connected approaches to researching the ways in which stigma may relate to the uptake of energy 
efficiency technologies in households as well as energy practices in general. The first acknowledges the fact that households might refuse to engage with the initiative as a direct result of seeing the 'targeted' energy efficiency scheme as compounding their already stigmatized status. In direct contrast, the second examines the possibility that households are reticent to take up the offer of targeted energy efficiency technology, because it may be regarded by their neighbours and friends as evidence of engagement in ideological practices which might be considered pretentious.

By drawing out this theoretically informed research agenda we encourage others to consider what role stigma might play, and how, if addressed, this might improve energy efficiency instalment rates. In order to conceptualise the relevance of stigma, this paper will draw on the sociological insights of Bourdieu's (1977, 1984, 1990, 1991, 1994, 1998, 2000) theoretical work. The remainder of the paper is organised as follows. In section 2, and bearing in mind the international audience of this journal, we provide some information about the nature of UK and Scottish energy efficiency policies which provides the empirical backdrop to our arguments. We have chosen to focus on Scotland because it has a similar performance in terms of the efficiency of housing stock to the rest of the UK, and England in particular, but operates under a different legislative freedom. Following section 2, section 3 reflects on some methodological considerations for taking this research agenda forward before in section 4, exploring the academic literature around energy efficiency and stigma. In the fifth section, we identify some of the ways in which current energy efficiency policies and approaches may be stigmatizing, before drawing the paper to a close with some conclusions and a programme for future research.

\section{UK and Scottish Approaches to Energy Efficiency - an overview}

Since the introduction of building requirements for energy efficiency in 1964 (in Scotland, then in England and Wales in 1966) (Dowson et al., 2012), there has been a progressive tightening of UK building regulations with regard to energy performance. Yet 58\% of current UK homes were built prior to these building regulations (Scott et al., 2014). Indeed, it has been estimated that between 70 and $80 \%$ of the existing poorly performing buildings will still be functional in 2050 (Pelenur and Cruickshank 2012). This recognition, coupled with the UK's statutory commitment to an $80 \%$ reduction in emissions by 2050 , means that there is a significant and pressing need to improve the energy, particularly thermal, efficiency of the UK housing stock. In addition to the benefits for householders, energy efficiency programmes have also been seen as a key mechanism to stimulate economic growth (Killip 2013, Latiner, 2015, Rosenow et al., 2014, Zhou et al., 2012) (irrespective of whether the initially stated goal is achieved), and there has been investment in UK retrofit initiatives over the past decade, although government funding in England, at least, has decreased more recently following the end of the Warm Front programme.

One measure of the efficiency of UK homes is $\mathrm{SAP}^{1}$, which it is proposed should rise to 80 by 2050 (Dowson et al., 2012). In Scotland, average SAP ratings in 2012 were 64.2, up from 62.6 in 2011, with half of all dwellings having an SAP rating of 67 of more (Scottish Household Survey 2013). In England in 2012 average SAP ratings were 59, up from 45 points in 1996 (English Housing Survey 2013). This demonstrates that Scottish homes are slightly better performing than English ones, although across both countries, SAP ratings vary according to age of the housing stock and tenure (typically, social housing has higher SAP ratings than private housing (see Ravetz 2008)). In terms of Energy Performance Certificates (EPC) ${ }^{2}$, in Scotland although there have been improvements in most

\footnotetext{
${ }^{1}$ The SAP is the Government's recommended system for energy rating of dwellings. The Standard Assessment Procedure is used for: 1) calculating the SAP rating, on a scale from 1 to 120 , based on the annual energy costs for space and water heating; and, 2) calculating the Carbon Index, on a scale of 0.0 to 10.0, based on the annual $\mathrm{CO}_{2}$ emissions associated with space and water heating (BREEAM 2010).

${ }^{2}$ EPCs were introduced through European legislation. They state the energy efficiency of a building based on standardised assumptions of use: with $\mathrm{A}$ being the most, and $\mathrm{G}$ being the least efficient rating. The certificate also indicates how the rating could change if specific improvements were made. EPCs are valid for ten years,
} 
types of homes, the worst performing (F and G) showed no significant change (Scottish Household Survey 2013) (largely due to them being hard to insulate given the predominantly solid wall construction). In England, there was an improvement in all bands of EPC, with the proportions of dwellings in the worst performing ( $F$ and G) falling (English Housing Survey 2013). Thus, the nature of the housing stock and its energy performance is comparable between Scotland and England.

Yet within the UK, the governance arrangements pertaining to energy are complex, and domestic energy efficiency is regulated in different ways. The Scotland Act 1998 which created a Scottish Parliament, was extended in The Scotland Act 2012, transferring the powers to make laws on a range of issues from the main UK (Westminster) government. The issues upon which the Scottish Parliament can make laws are known as devolved powers. Energy policy is a matter that is reserved to the UK parliament (i.e. not devolved) which means that only Westminster can make decisions on, for example, the generation, transmission, distribution and supply of electricity (e.g. the recent Electricity Market Reform). However, housing, land use planning and regeneration are devolved policy matters, meaning that the Scottish Parliament has legislative responsibility for these issues. As a consequence, across the UK there are differences in the ways in which energy efficiency policies are designed, developed and implemented. In England and Wales, for example, previous policies included the Warm Front Scheme and the Carbon Emissions Reduction Target (CERT) which provided meanstested or disability-related subsidy for home energy efficiency improvements. These have been replaced as part of the UK's Energy Act, specifically the Energy Company Obligation (ECO) which will run alongside the existing non-means tested Winter Fuel Payment and Warm Home Discount Scheme (HM Government 2010). So far, evaluations as to the effectiveness of these policies suggest that their success has been mixed (Brown 2015; Dowson et al., 2012; Mallaburn and Eyre 2014).

In Scotland, energy efficiency policies are different from the rest of the UK. There are also particular, distinct challenges in terms of the Scottish housing stock which compared with the rest of the UK: 1) has a higher proportion of solid wall properties making retrofitting expensive and; 2) has a higher proportion of properties not connected to the main gas grid which makes them more expensive to heat. In addition to these challenges, the Scottish climate means there is a greater requirement for heating. Hence, a focus on Scotland and Scottish energy efficiency policies is particularly welcome given that there is potential for a greater number of people to be affected by these policies.

There has recently been change in Scottish Government energy efficiency policies. For instance, the Home Energy Efficiency Programmes for Scotland (HEEPS) was launched in 2013 to increase energy efficiency in homes (Energy Action Scotland 2014). HEEPS is a cluster of programmes including, for example: Affordable Warmth, Area Based Schemes (ABS), and the Energy Assistance Scheme, and is run in partnership through a number of advice providers, namely the Energy Saving Trust, and energy companies (ibid). HEEPS replaces the previous policies of the Energy Assistance Package, Universal Home Insulation Scheme and the Boiler Scrappage Scheme (ibid). The qualifying criteria for assistance via one of these schemes is typically that someone in the household is in receipt of certain social security benefits and/or has elderly (60+) or vulnerable occupants, but some of the schemes are also for owner occupiers and tenants of private landlords. There is a considerable amount of funding associated with HEEPS. For instance, ABS has a budget of £60m for 2014-15 (ibid) with additional funds available via ECO, although these have to be applied for. ABS follows an area-based approach, delivered by local authorities, with initial focus on the most deprived areas and will draw on a range of data including indices of multiple deprivation, child poverty, the Scottish House Condition Survey and heat mapping (Energy Action Scotland 2014). The inclusion of an area-based scheme as part of HEEPS is notable. The Housing Studies literature has explored the merits of such schemes, largely as a method to tackle issues of poverty and inequality (Manley et al 2013; McKee 2011a). The use of an area-based scheme to deal with energy efficiency, and its potential stigmatising effects, is something that we return to in section 4.

and can only be produced by an approved assessor. All domestic and commercial buildings in the UK being made available for rent or sale must have an EPC. 
In addition to HEEPs, other policy measures are influencing domestic energy efficiency. Last year the Scottish Government published details on a new Energy Efficiency Standard for Social Housing (EESSH) (see: http://www.energyefficientsocialhousing.org/). The social housing sector in Scotland has been at the forefront of innovation in terms of energy efficiency. Yet with a growing number of people in Scotland privately renting (circa 14\% of households), there is more that can be done to target and improve the energy efficiency of the private rented sector stock (McKee and Hoolachan 2015). It is clear that for all tenures, the impact of energy efficiency improvements could be significant and is worth further consideration.

\section{Theoretical and Methodological considerations for progressing this research agenda}

This paper draws on the theoretical and methodological insights of Pierre Bourdieu who, as one of Europe's leading sociologists, offered a highly nuanced set of thinking tools for understanding human practices. Bourdieu's social anthropology is based on a central thesis that one of the fundamental predicates of the human condition is the "universal dependence on the judgement of others" (2000: 100). Constructing a sociological model which moves beyond the narrow economic determinism of Marxian thought, Bourdieu (1990, 1991, 1998, 2000) developed the notion of what he calls symbolic capital, a concept which provides a radical alternative to the 'utilitarianism' (Bourdieu 1998) espoused by those advocating the epistemic virtues of theories relating to the 'rational choice actor'. Bourdieu's strategy for understanding what he calls the fuzzy logic of practical sense (Bourdieu 1977, 1990, 1991, Bourdieu and Wacquant 1992) was to move beyond social physics (objectivism) and social phenomenology (subjectivism) by focusing on the dialectical relation between the two. This relationship is evident in the shared norms and values, as well as the categories of perception that agents intersubjectively apply to the world and everything in it. These collective conventions, like the dispositions of individuals, are largely defined by their location in social space, which is itself largely determined by the structure and volume of the economic, cultural and social capital the agent (as well as those within close proximity) possess. Not only are these collective conventions marks of 'distinction' (taste, political opinion, ways of walking, talking and therefore thinking) which set people and groups 'apart', they are used in the struggles for 'recognition' between groups who compete for the monopoly over the legitimate right to define reality (Bourdieu 1990, 1991, 1998, 2000).

An example of how this 'dialectical' process works is evident in the way that certain objects and practices serve to reinforce social distance by reproducing the various forms of symbolic capital which when (mis)recognised as legitimate, leads to the double naturalisation of the social world, itself an effect of the accord between objective structures and mental and bodily schemata (Bourdieu 1990, 1998). A fine art painting hanging on the wall of a prestigious stately home enjoys the symbolic capital that its 'location' gives it. The reputation of the stately home is enhanced with every great art work which hangs on its walls. These two factors ('old masters' and 'stately homes') confer upon the occupants a significant degree of symbolic capital. A form of social magic has thus been performed (Bourdieu 19991) and what is little more than an economically determined, socially constructed, historical field (fine art and its patrons), now appears as a 'wholly natural' reality. Because mental structures tend to be more or less adequately adjusted to objective structures, reality tends to be unquestioningly accepted by those who experience it. This voluntary acceptance of 'the-way-thingsare' is also the foundation of what Bourdieu $(1990,1991,1994,2000)$ calls symbolic violence, that is, the complicity of the dominated in their own domination through their inability to 'recognise' the arbitrary nature which underlies all forms of power. This more nuanced concept of 'symbolic capital' displaces the 'basic' notion of 'status', a rather one dimensional construction which favours the economic over the cultural, the practical over the symbolic. Substituting 'status' with the concept of 'symbolic capital' provides an analytical lens which is better suited to viewing the various forms of cultural (as well as economic) domination by some groups over others.

In opposition to this form of 'status' sits 'negative symbolic capital', a term which is often referred to in its more simplistic form, as stigma. In opposition to the symbolic profits which accompany the 
social practices of those who occupy superior positions in social space, there exist the negative symbolic attributes which accompany the social practices of those who are excluded and marginalized. The 'poor neighbourhood' denigrates its citizens who in turn denigrate the area in a tautegorical process of mutual denigration (see Bourdieu et al 1999, Wacquant 2009).

This is of relevance to this paper because, as Bourdieu (1984) argues, the core values of the dominant tend to become the bench mark of all other cultural practices. Indeed, as Batty and Flint (2013) demonstrate in their seminal paper on comparative poverty in stigmatized neighbourhoods, the fact that humans have a drive to evaluate themselves against others, leads, in certain circumstances, to powerful levels of anxiety about their status. Their research shows that "individuals on low incomes are very concerned about stigma, negative images and stereotyping... which generates a 'spoiled' or 'discredited' identity contributing significantly to low self-esteem, exacerbated by feelings of being 'looked down on' or being a scrounger or good for nothing" (Batty and Flint 2013: 4). Indeed, of great relevance to this paper Batty and Flint make the claim that "class can also be used against those positioning themselves as 'higher', including snobs" (2013: 4).

Another theoretical and methodological consideration of relevance for this paper relates directly to what Bourdieu (1990, 1991, 1998, 2000) calls 'scholastic bias', an academic practice which involves the researcher, projecting their own 'categories of perception' (which are of course culturally and historically shaped by that person's location in social space) into the minds of those whose practices are being studied. Influenced by the work of Bourdieu we argue the academic treatment of stigma is therefore problematic on two levels. Firstly, those who research stigma, or who make policies to tackle the problem, rarely if ever, come from the stigmatized groups themselves. This raises issues concerning the limits of understanding, invoking Bourdieu's notion of a 'scholastic bias', where the academic (or policy) categories of perception which are applied to the world are inserted into the minds of those who are being researched. This point is directly relevant to that made above, in that the volume and structure of capital (both economic and cultural) will differ between researchers, policy makers and marginalised groups, so will influence their dispositions, preferences and concerns (see Comment and Debate in Housing Theory and Society edited by Clapham 2011). The point which Bourdieu (1990, 1991, 1998, 2000) emphasizes is that a person's social practices, including the ways in which they think about the world, are largely influenced by their proximity to economic necessity. Individuals who have the leisure time to ponder the world from an objectivist position will inevitably see the world differently from those whose lives are largely consumed by the necessities of labour and their daily struggles to get by. The second criticism is also directly related to the above in that it focuses heavily on the individual. Quoting Goffman, Link and Phelan (2001: 364) assert that a systematic study of stigmatizing practices show that stigma is more about "relations than attributes" a salient fact which must be acknowledged in any research methodology which aims to examine negative forms of symbolic capital otherwise known as stigma.

In accordance with Bourdieu's theory/method nexus two issues have been dealt with in this section. Firstly, Bourdieu's social anthropology provides a useful way to understand the 'fuzzy logic of practical sense' (Bourdieu and Wacquant 1992: 6) and secondly, this section shows how a reflexive sociological method can overcome forms of scholastic bias which may hinder social research on energy practices.

\section{Literature Review}

In this section of the paper we seek to move on from the contemporary political context outlined in section 2, and theory/method in section 3, to explore key academic literatures around domestic energy efficiency research and stigma. In so doing, we refer to important texts, demonstrate areas of consensus and disagreement, and identify critical research gaps. 


\section{Domestic energy and efficiency: what the research says}

The type and amount of energy used, for what, when and why, is intimately tied to issues of efficiency. Thus, instead of encouraging householders to simply use less energy, the implicit policy message is to do the same with greater efficiency. At the same time, attention in the literature has focused on the interconnected nature of energy supply and demand, represented by a change from discussions about energy use and consumption to those of energy demand (Shove and Walker 2014). This is a nuance not often acknowledged in the housing research literature and perhaps also arises from the growing contribution of more sociological thinking which is increasingly using practice theories (Shove 2003) to draw attention to the wider structural issues influencing energy demand in homes. Such a trend has also meant that issues like comfort and homeliness are gaining traction in the academic literature related to domestic energy research (Ellsworth-Krebs et al., 2015, and the 2015 special issue of Building Research and Information).

In terms of the domestic energy efficiency literature, five key areas can be identified: 1) building performance and design; 2) patterns of energy consumption across household types and fabrics; 3 ) take up of energy efficiency measures (Hamilton et al., 2014, Wilson et al., 2015); 4) the behaviours or practices of occupants both in relation to energy demand but also in terms of how householders interact with energy efficiency technologies (Chappell and Shove 2005, Hand et al., 2005); and, 5) the development of policy. Common amongst these areas, is a recognition that building performance differs significantly from what is anticipated during design (Cole 2010) or predicted from SAP ratings (Gupta and Chandiwala 2010, Kelly et al., 2012). For instance, studies by Gram-Hanssen (2010) and Gill et al. (2010) found that occupants can use two or three times more energy than their neighbour, while in the exact same type of home with the same number of occupants ( $\mathrm{Li}$ and $\mathrm{Lim} 2013$ ).

Attempts to explain this phenomenon, often referred to as the building performance gap (Gill et al., 2010), are increasingly moving beyond traditional post-occupancy evaluations (POE) questionnaires, and undertaking more in-depth qualitative analysis about the experiences of retrofitting (Cole 2010, Cooper 2001). However, there remains a reliance on surveys as the means to understanding such experience, and to our knowledge, there is a lack of literature on the subjective experiences of specific groups. Where there is research in this area, it predominantly focuses on homeowners and their voluntarily changing their homes (Butler et al., 2014a, Butler et al., 2014b, Gram-Hanssen 2010, 2014). However, in one recent notable study, Scott et al., (2014) explored the experience of residents in areas of Yorkshire and the Humber in response to the Big Energy Upgrade. In that area-based scheme, communities were identified for a wide range of energy efficiency interventions on the basis that they were in the $10 \%$ most 'deprived' areas as determined by the UK government's index of multiple deprivation. Key findings of that study were that in order to encourage residents in these areas, empowerment and responsibility rather than belief about climate change would be key to greater uptake. Moreover, "positive beliefs were not necessarily based on improved energy efficiency, as expected, but were based on anticipating that the scheme would have a positive impact on the appearance of homes and communities" (Scott et al., 2014: 346). However, this specific study was undertaken using a questionnaire, often closed answers, and attempted to explore attitudes and intentions in relation to climate change and energy efficiency interventions. The methodology used thus foreclosed the opportunity to understand the subjective experiences of participants.

Similarly, technological solutions to the building performance gap gloss over the experiences or feelings of householders in relation to these interventions. In the UK as with many other EU nations, the government is moving towards a compulsory roll-out of smart meters by 2020 . These will have an In Home Display (IHD) to demonstrate use and cost of energy, as some research has documented the effect that making energy more visible might have on its use (D'Oca et al., 2014, Hargreaves et al., 2010). However, there are concerns around household perceptions of 'big brother' spying on households and issues of trust which may generate resistance to such technology (Spence et al., 2015). Thus, there are some challenges or limits to the ability of new technological innovations. Take for example the regulations related to the energy efficiency of appliances; despite improving efficiency of appliances, appliances do still tend to use more energy than before and are being bought 
and used in ever greater quantities, cancelling a large proportion of the energy saving (Energy Savings Trust 2014). Hence, the literature on energy efficiency is still demonstrating that despite some homes and appliances being designed to use as little energy as possible, energy efficiency is not always fully achieved. Greater understanding of why this is the case is required.

There has clearly been a mass of research on domestic energy efficiency, some of which do demonstrate that energy efficiency practices are becoming more 'normalised' (Shirani et al., 2015). Despite this, however, we suggest that there has been a neglect of the subjective experiences of energy efficiency, and in particular that the implications of energy consumption and energy efficiency with respect to stigma have been almost entirely ignored. In one of very few publications on the topic, Hards (2013) suggests that conspicuous energy consumption and energy conservation can be both status enhancing and generate stigma. As she reflects "energy practices are deeply contextual....shaped by inequity and power" (Hards 2013: 449). The remainder of this literature review thus explores issues of stigma and how they might relate to energy practices.

\section{Stigma, Consumption and Everyday Energy Practices}

In the energy efficiency literature stigma has received much less academic attention than the related idea of status (Hards 2013), yet it is critical to understanding the impact of everyday practices. In broad terms stigma can be thought of as a label, which both stereotypes and differentiates 'us' from 'them', the effect of which is discrimination (Link and Phelan 2001). This approach is derived from Goffman's (1968) seminal idea of 'spoiled identity'. However, we argue it is helpful to move beyond labelling theory, and theorise stigma in terms of consumption practices. This enables us both to tease out the way in which specific energy practices may carry a 'stigma-risk' (Hards 2013), and also to underline how citizenship itself is inextricably bound up with consumption, and imbued with relations of power (Allen 2008; Flint 2003; McKee 2011b; Warde 2005). Whilst Hards' (2013) study highlights no 'serious stigma' around energy practices, cases of embarrassment and mockery were described. Moreover, it was clear that people were 'actively managing' the potential stigma associated with their energy consumption practices. These conceptual links between stigma and consumption potentially open up a new and interesting research agenda worthy of further exploration. As debates within Sociology highlight, consumption practices are inextricably linked to differential access to various types of capital (e.g. economic, social, cultural), and are thus bound up with class position (Bourdieu and Wacquant 1992). The work of Bourdieu is particularly insightful in this respect (Brubaker 1985; Calhoun 2003).

The sub-sections to follow will unpack these ideas further by highlighting two possible lines of enquiry into understanding the connections between energy consumption practices and notions of stigma. These approaches can be conceptualised as follows: firstly, the targeted intervention stigmatises the intended recipient; and secondly, the practices of energy efficiency are criticised as being 'pretentious' by the recipient's neighbours. Both sections are exploratory, marking out a research gap for further study, however in doing so they draw on existing literature from Housing Studies informed by research on stigma in low-income neighbourhoods, as well as long-standing debates within Sociology regarding the conceptualisation of stigma.

\section{Understanding energy practices in a socially stratified world.}

This first conceptual approach is perhaps the most straight forward in so far as it is based on the premise that stigma, although a contested concept, is at its core a power relation, which individuals and groups invoke, in order to either "keep people down, keep people in, or keep people away" (Link and Phelan 2001: 25). Drawing on Bourdieu and Goffman, Link and Phelan (2001) tackle stigma from the point of view of what they call "the stigma-power concept". This is relevant as those who are from stigmatized groups will have some level of awareness of the fact that their "low status" is the source of their stigmatization, a result of three distinct processes (Link and Phelan 2013: 1) 'labeling' differences; 2) associating these differences with negative attributes; and, 3) as a mechanism for 
separating 'us' from 'them'. Status loss and discrimination play a significant part in this model which, based on the theoretical principles surrounding labeling theory, is useful for researchers as it offers a robust account of why someone from an already disadvantaged group would understandably shy away from initiatives that mark them out as such, thus reinforcing their negative symbolic capital (Bourdieu 2000).

This is the approach adopted by Hards (2013) in exploring the ways in which status and stigma affect energy consumption practices. The argument presented by Hards suggests that energy consumption is both a way of conferring status, through conspicuous consumption, or stigma through a person's inability to conform to societal norms with regard to energy consumption. Drawing on Bourdieu, Hards highlights the double edged nature of status/stigma showing how conspicuous conservation among certain groups creates a form of 'green distinction', which itself is a form of symbolic capital. Had Hards more comprehensively used the Bourdieusian conceptualisation she could have made better use of the notion of 'negative social capital', which Bourdieu $(1984,1991,2000)$ invokes to not only show the relationship between status (symbolic capital) and stigma (negative symbolic capital), but also how they reinforce each other through the dialectical processes of daily practice.

As such, and continuing with this idea of a stratified hierarchy based on consumption, Sociologists like Bourdieu (1984) have illuminated the way in which consumers of cultural goods and their tastes for them are produced. For such scholars, status is intimately bound up with notions of stigma, with expressions of taste acting as a key source of social (class) distinction:

"Social subjects [...] distinguish themselves by the distinctions they make, between the beautiful and the ugly, the distinguished and the vulgar, in which their position in the objective classifications is expressed or betrayed" (1984: 6).

The mobilisation of different forms of capital, including social, economic, cultural and symbolic is important here in both establishing one's status position, but also in avoiding stigma (Hards 2013). This argument has already been well developed and explored within Housing Studies research, most notably the work of Allen (2008), Arthurson et al., (2014), Batty and Flint (2013), Flint and Rowlands (2003), McIntyre and McKee (2008, 2012), McKee (2011b) and Rowlands and Gurney (2001). The work of Damer (1989) and Hastings (2004) in particular draw attention to the key role of external actors and influences in these processes. Uniting this body of work is an emphasis on the role of discursive practices and governmental interventions in normalising and elevating particular forms of housing consumption (e.g. tenures). As Rose highlights in his work on ethopolitics, consumption plays a pivotal role in a governance project aimed at shaping identity, with governable subjects expected to "self-craft one's existence according to a certain art of living" (2001: 5; see also Flint 2003, McKee 2009). Academics influenced by Wacquant's (2008) work on 'territorial stigmatisation' have drawn attention to the spatial dimension of these governance shifts (Hancock and Mooney 2013, Slater 2014). This is important, for energy efficiency policy in Scotland operates with an area-based focus, with presumptions made about energy practices based on indices of neighbourhood level deprivation. This is just one approach of energy efficiency policies, others being, for example those such as the Green Deal (an opt-in subsidy for owner occupiers) or information raising campaigns. Yet all of these polices involve some form of 'targeting' which may present more or less stigma-risk that should be explored through further empirical work. What is specific to area-based schemes, however, is that they not only treat diverse neighbourhoods in a very homogenous way, but more fundamentally ignore that the "problems in the neighbourhood are seldom problems of the neighbourhood" (Andersson and Musterd 2005:386), such as for instance, why were homes of poor energy efficiency built in the first place? Undoubtedly, other energy efficiency approaches fail to address this question too which brings us back to the question of why, for some households rather than others, energy practices might carry a greater risk of stigma.

The Housing Studies literature clearly highlights that housing is a phenomenon and system subject to stigmatisation. Yet these arguments have not been explored in relation to energy-efficiency programmes, where the predominant focus has been on the related idea of status. Whilst Telfer 
(1984) suggests energy conservation carries negative connotations of 'doing without', or stinginess, other studies have drawn attention to the ways in which particular technologies were regarded as 'trashy' or 'low-class' (Strand, in Hards 2013). Energy-saving technologies are therefore not always regarded as 'eco-bling' (Hards 2013). The social psychology literature also indicates that people engaged in potentially stigmatising practices may adopt strategies of resistance (Link and Phelan 2001), and this may manifest itself in controlling the visibility of stigmatising practices, and avoiding discussing them with others (Hards 2013). It would seem then that the interconnections between energy and stigma varies significantly depending on the specific social context, with empirical research needed to better understand how this plays out in practice, in different places in different ways. Indeed Link and Phelan $(2001,2013)$ stress that stigma (as well as status) exists as a matter of degree. This complicates the issue for researchers trying to understand why households are reluctant to engage with energy efficiency technologies as occupiers of targeted households will have varying levels and degrees of both positive and negative forms of symbolic capital. It therefore makes it extremely difficult to say with any great certainty that occupiers who refuse to engage in energy initiatives do so on the grounds that it compounds their sense of 'difference', or 'inadequacy' as a direct result of an awareness of being seen as 'failed consumers'. Indeed, for low status individuals and groups, the notion of 'separating us from them' (or them from us), the marking out of difference has two very sharp facets, which leads on to our next point.

\section{The Constraining Force of Negative Symbolic Capital}

This second conceptualisation revolves around the notion that householders in the 'targeted' group may feel uncomfortable about being 'judged' by their neighbours and friends for engaging in practices which are regarded as being 'pretentious' due to the fact that they are much more common among groups who possess higher levels of both cultural and economic capital that those in the targeted group. This is articulated in the writing of Wacquant $(2008,2009)$, whose empirical work catalogues the causes and effects of various types of stigma in the urban metropolis, in both Europe and the US. In explaining the difficulties faced by residents trying to extricate themselves from stigmatized areas he notes:

“... the possibility of realizing the primitive accumulation ${ }^{3}$ of resources needed for upward mobility is eroded by the predatory cast of relations between residents and by the pressure toward social uniformity which weighs on those who try to rise above the poverty level common to most people in their area" (Wacquant 2008: 178).

This phenomenon is similar to Craig's $(2010,2011)$ observations of working class life in Scotland where neighbours not only become resentful of those who are trying to get on, which is the beginning of a process of getting out, (Atkinson and Kintrea 2001) but actively pull them back through their critical capacity of articulating the various forms of negative symbolic capital which lead to selfenforced social containment, such as the various colloquial tropes of; 'who does s/he think s/he is?' or 'S/he would be wise to remember where s/he comes from' etc. This accords with Bourdieu's (1991, $1999,2000)$ assertion that symbolic violence ${ }^{4}$ leads the dominated to actively participate in their own domination, through their wholesale acceptance of their place and the place of others, in the world. The question, related to this conceptualisation that requires further research is - to what extent are the targeted householders reticent to engage with energy saving technologies for fear of 'limiting and critical judgment' from neighbours who may thus regard them pejoratively as 'getting above their station' (Craig 2011). This reinforces the forms of negative symbolic capital (Bourdieu and Wacquant 1992) which, from the perspective of the dominated, regard 'aspirational' behaviour as being 'not for the likes of us' which means:

\footnotetext{
${ }^{3}$ Primitive accumulation is a Marxian term developed by Harvey (2014) to account for the initial forms of capital a person requires to 'set themselves up' or in this case to get out of the stigmatised neighbourhood. ${ }^{4}$ Symbolic violence occurs when the dominated submit (without conscious awareness) to the dominant categories of perception which mask the arbitrary foundation of all forms of 'legitimate 'power (Bourdieu 2000)
} 
“...adjusting their expectations to their chances, defining themselves as the established order defines them, reproducing in their verdict on themselves the verdict the economy pronounces on them, in a word, condemning themselves to what is in any case their lot" (Bourdieu 1984)

This conceptualization of the problem suggests that even if targeted householders are aware of the benefits of energy saving technologies, on both the environment and their own financial position, they will be reluctant to engage for fear of being cast as a 'snob', or as 'having pretentions' (see Batty and Flint 2013). This form of peer pressure to conform to the norms of low-income neighbourhoods needs rigorous empirical testing, which can be carried out by interviewing those affected, using the kind of sensitive and reflexive methodology which neither stigmatises nor judges the actions or inactions of households.

\section{Discussion, conclusions and a future agenda}

At the outset of this paper, we declared an interest in exploring how being identified or targeted for energy efficiency improvements, and how the processes of installation, may potentially stigmatize households. What we have demonstrated in our review thus far is that while limited, there is some work on stigma in relation to energy consumption and practices. However, the relationship between stigma and interventions to promote energy efficiency has been largely ignored. In the remainder of this paper we put forward some suggestions about how this relationship may be manifest, whilst also identifying some opportunities for future research. A caveat is needed here, for much of this postulating is just that, there is a real, and pressing, requirement to undertake work with households to explore whether energy efficiency interventions are stigmatizing. Informed by a productive view of power ${ }^{5}$, we recognise that those 'targeted' for such interventions ultimately have the capacity to reject the subject positions created for them as 'stigmatised' households (McKee 2009). It would also enable us to tease out the relational dimension of stigma (Parkhill et al., 2013), for it is ultimately a social process underpinned by a normative judgement that demarcates particular places, people or practices as different. Above all is, stigma reflects a relationship of power.

To operationalise these conceptual arguments careful attention must be given to research design, specifically how to develop a theoretically informed sample that allows stigma to be explored in all its nuances. As we have suggested, there are likely multiple and complex ways in which the relationship between energy efficiency and stigma may be manifest. Throughout this paper we have alluded to three key elements through which this relationship may be influenced. These are:

1. The nature of the energy efficiency technology, and in particular its visibility;

2. The nature of the dwelling (and by this we are including both the building fabric and the tenure type);

3. The income level of the household;

Thus, the relationship between energy efficiency and stigma is likely to be influenced by these three variables, and the 'stigma-risk' (Hards 2013) of any given household will differ according to the relative combinations of each. For instance, housing tenure may influence the autonomy that a household has to make changes to the building fabric (e.g. homeowners have more freedom to make improvements than renters). Tenure is further an interesting facet given shifting housing tenure structures in the UK (and internationally), which has resulted in a decline in homeownership and rise in private renting. Private rented housing is not required to meet the same building quality and energy efficiency standards that are required of social landlords in the UK, moreover, there is arguably less incentive for private landlords to invest in technologies given they will not be residing in the property nor paying its energy bills. In addition, the quality of the building fabric will dictate different forms

\footnotetext{
${ }^{5}$ Theories of power as 'productive' are influenced by post-structuralised theory on the production and creation of particular types of governable subject e.g. the empowered consumer, responsible citizen (see McKee 2009).
} 
of energy efficiency improvements (e.g. external cladding versus cavity wall). Moreover, the income of a household may influence the ability of a household to fund any improvements (though of course it could be that households qualify for free or subsidised installation), whilst the nature of the technology may also have an effect on installation, since some forms of technology are cheaper than others, and some are more visible than others. A caveat is required here for different policies target different elements - for instance, some policies may target poor quality housing stock (dwelling), others may target households on low incomes where members are in receipt of social security benefits, whilst others may promote particular technologies (e.g. external cladding, double glazing, loft installation). Thus, different policies may prioritise different elements which may lead to varying degrees of stigmatization. However, it may be that there are particular combinations of these elements which give rise to more or less stigma-risk, and we can begin to hypothetically 'categorize' these. As Hamilton et al., (2014) have demonstrated, households in England which are middle income and owner occupied are less likely to uptake energy efficiency improvements. Alternatively, rented properties that have occupants on low incomes may present different types of stigma-risk. That is not to say that all owner occupiers have middle incomes, or that those in the private rented sector, or who are social housing tenants have low incomes. The Housing Studies literature clearly highlights inequalities within as well as between housing tenures. The visibility of different technologies may also play a role. For those in social housing, a visible installation such as external cladding/insulation or new double glazed doors and windows may be potentially stigmatizing as these householders are viewed by others as being in receipt of 'help' and hence 'dependent' on the state. In theoretical terms much of the literature on stigma has been informed by debates around class, consumption and taste with distinctions made between those with differential degrees of social, economic and cultural capital. Whilst the Housing Studies literature has tended to focus on the experiences of low-income households in 'deprived' (social housing) neighbourhoods, we argue, there is merit in expanding our empirical focus to also include more affluent households, and households drawn from different tenures. Doing so would allow us to unpack the complexity of potential stigma risk, and empirically evidence our theoretical arguments.

In addition, as outlined in the introduction, area-based initiatives are particularly interesting given the emphasis on 'place' within Housing Studies research on stigma. Yet as the literature emphasises "the driving mechanisms behind area-based initiatives tend to ignore, or at least underplay, structural factors determining urban social problems such as poverty and social exclusion" (Andersson and Musterd 2005:379), hence questions such as why thermally inefficient homes exist, and who lives in them, are not adequately tackled. This takes us back to the arguments made earlier regarding choice, aesthetics and taste emerging from the sociological literature on consumption, class and culture. As such we perceive there could be a high stigma-risk of this particular policy approach, which is of concern in so far as people may be reluctant to take up energy efficiency interventions, thus leading to an unintended policy outcome (e.g. undermining take-up of specific technologies). It would therefore be desirable to undertake an in-depth examination of energy efficiency area-based schemes in order to understand the processes and organizations involved in delivering high levels of targeting, identifying methods of best practice.

Taking these ideas forward, and as we have repeatedly made clear, there is an emerging agenda for housing researchers, policymakers and practitioners. This includes, and as a priority, empirical work to explore the experiences of those in receipt of energy efficiency interventions. Working with colleagues in other EU countries to explore how energy efficiency stigma may be differently experienced would also be an important step forward. Geography is important given housing, land use and regeneration policy varies within the UK, as well as between the UK and other countries. This demands qualitative research to understand people's subjective experiences and the relational processes at play, but also recognition (after Bourdieu) that theory and method are inextricably linked.

To conclude, we set out to explore whether a relationship between energy efficiency and stigma may exist. In order to be fully circumspect, this paper has addressed the issue of what Bourdieu (1990, 1991, 1998, 2000) calls 'scholastic bias'. This is important as it provides a degree of reflexivity concerning the researcher's own 'point of view'. By accounting for the forms of economic and 
cultural capital required to 'take seriously' issues of energy consumption, researchers can become aware of the social conditions which have shaped their own opinions on the relationship between energy efficiency technologies and the various forms of symbolic capital (both positive and negative) which surround them. Whilst we have not (yet) undertaken any empirical work to test the relationship between energy efficiency and stigma, it does seem that this offers a fruitful avenue for future research and would help address the gap that exists in current energy efficiency research in terms of subjective experience - we present our own emerging research agenda as a way to encourage future collaboration in this area.

\section{Acknowledgements}

The lead author was supported by the Economic and Social Research Council [grant number ES/K009516/1]. Thank you to the referees and editor of Energy Research and Social Science for their very constructive and engaging comments; responsibility as ever lies with the authors.

\section{Bibliography}

Allen, C. (2008) Housing Market Renewal and Social Class. London: Routledge

Andersson, R. and S. Musterd (2005) "Area-based Policies: a critical appraisal”, Tijdschriftvoor Economische en Sociale Geografie, 96 (4): 377-89.

Atkinson, R. and Kintrea, K. (2001) "Disentangling Area Effects: Evidence from Deprived and Non Deprived Neighbourhoods", Urban Studies 38 (12): 2277-98.

Arthurson, K.; Darcy, M.; and Rogers, D. (2014) “Televised Territorial Stigma: how social housing tenants experience the fictional media representation of estates in Australia", Environment and Planning A 46: 1334-1350.

Batty, E. and Flint, J. (2013) “Talking 'Bout Poor Folks (Thinking 'Bout My Folks): perspectives on comparative poverty in working class households", International Journal of Housing Policy, 13 (1): $1-19$.

Bourdieu, P. (1977) Outline of a Theory of Practice. . R. Nice, transl. Volume 16. Cambridge: Cambridge University Press

Bourdieu, P. (1984) Distinction. London: Routledge.

Bourdieu, P. (1990) The Logic of Practice. London: Routledge.

Bourdieu, P. (1991) Language and Symbolic Power. London: Routledge.

Bourdieu, P. (1994) "Rethinking the State: the genesis of the bureaucratic field", Sociological Theory, 12 (1): 1-18.

Bourdieu, P. (1998) On Practical Reason: on the theory of action. California: Stanford University Press

Bourdieu, P. et al (1999) Weight of the World. Cambridge: Polity.

Bourdieu, P (2000) Pascallian Meditations. London: Polity Press.

Bourdieu, P. and Wacquant, L. (1992) An Invitation to Reflexive Sociology. London: Polity.

BREEAM (2010) Code for Sustainable Homes, from: http://www.breeam.org/page.jsp?id=86

Brown, M. (2015) “Innovative Energy-Efficiency Policies: an international review”. Wiley

Interdisciplinary Reviews: energy and environment 2015 4: 1-25. 
Brubaker, R. (1985) "Rethinking Classical Theory: the sociological vision of Pierre Bourdieu, Theory and Society" 14 (6): 745-775.

Brunner, K., Spitzer, M., Christanell, A (2012) "Experiencing Fuel Poverty: coping strategies of lowincome households in Vienna/Austria", Energy Policy 49:53-59

Butler C., Parkhill, K. A., Shirani, F., Henwood K., and Pidgeon, N. (2014a) "Examining the Dynamics of Energy Demand through a Biographical Lens", Nature + Culture 9 (2): 164-182

Butler C., Parkhill, K. A., and Pidgeon, N. (2014b) "Energy Consumption and Everyday Life: choice, values and agency through a practice-theoretical lens", Journal of Consumer Culture 19 (online early)

Calhoun, C. (2003) "Pierre Bourdieu”, pp 274-310. In Ritzer, G. (ed) The Blackwell Companion to Major Contemporary Social Theorists. Oxford: Blackwell.

Chappell, H. and Shove, E. (2005) "Debating the Future of Comfort: environmental sustainability, energy consumption and the indoor environment", Building Research and Information 33(1): 32-40.

Clapham, D. (2011) "Introduction to Comment and Debate - responses to the Special Issue: a theory of housing: problems and potential", Housing Theory and Society 28 (1): 1.

Craig, C. (2010) Tears that Made the Clyde. Argyle Publishing: Edinburgh

Craig, C. (2011) The Scot's Crisis of Confidence. Argyle Publishing: Edinburgh

Cole, R. (2010) "Green Buildings and their Occupants: a measure of success", Building Research and Information, 38 (5) 589-592.

Cooper, I. (2001) "Post-Occupancy Evaluation-Where are You?" Building Research and Information 29 (2): $158-163$.

Damer, S. (1989) From Moorepark to Wine Alley: rise and fall of a Glasgow housing scheme. Edinburgh: Edinburgh University Press.

Day, R. and Hitchings, R. (2011) ““'Only Old Ladies Would do That': age stigma and older people's ways of dealing with winter cold" Health and Place 17 (4): 885-894

D’Oca, S., Corgnati S. P., and Buso, T. (2014) "Smart Meters and Energy Savings in Italy: determining the effectiveness of persuasive communication in dwellings", Energy Research and Social Science 3: 131-142.

Dowson, M., Poole, A., Harrison, D., and Susman, G. (2012) "Domestic UK retrofit challenge: barriers, incentives and current performance leading into the Green Deal", Energy Policy, 50: 294305 .

Energy Action Scotland (2014) http://www.eas.org.uk/page.php?id=3206

English Housing Survey (2013)

https://www.gov.uk/government/uploads/system/uploads/attachment_data/file/284648/English_Housi ng_Survey_Headline_Report_2012-13.pdf

Energy Savings Trust (2014) Powering the Nation, http://www.energysavingtrust.org.uk/reports/powering-nation. 
Ellsworth-Krebs, K., Reid, L., and Hunter, C (2015) "Home-ing in on Domestic Energy Research: 'House', 'home', and the importance of ontology", Energy Research and Social Science 6:100-108.

Flint, J. (2003) "Housing and Ethopolitics: constructing identities of active consumption and responsible community", Economy and Society 32 (4): 611-629.

Flint, J. and Rowlands, R. (2003) "Commodification, Normalisation and Intervention: cultural, social and symbolic capital in housing consumption and governance", Journal of Housing and the Built Environment 18 (3): 213-232.

Gill, Z. M., Tierney, M. J., Pegg, I. M., and Allan, N. (2010), "Low-energy Dwellings: the contribution of behaviours to actual performance", Building Research and Information 38 (5): 491508 .

Goffman, I. (1968) Asylums. Harmondsworth: Penguin.

Gram-Hanssen, K. (2010), "Standby Consumption in Households Analyzed with a Practice Theory Approach", Journal of Industrial Ecology 14 (1): 150-65.

Gram-Hanssen, K. (2014). Retrofitting Owner-Occupied Housing: remember the people, Building Research and Information (ahead-of-print): 1-5.

Gupta, R. and Chandiwala, S. (2010) "Understanding Occupants: feedback techniques for large-scale low-carbon domestic refurbishments", Building Research and Information 38 (5): 530-48.

Hamilton, I., Shipworth, D., Summerfield, A., Steadman, P., Oreszczyn, T., and Lowe, R (2014) "Uptake of Energy Efficiency Interventions in English dwellings", Building Research and Innovation, 42 (3): 255-275.

Hancock, L. and Mooney, G. (2013) “"Welfare Ghettos' and the 'Broken Society': territorial stigmatization in the contemporary UK", Housing Theory and Society 30 (1): 46-64.

Hand, M., Shove, E., and Southerton , D. (2005) "Explaining Showering: a discussion of the material, conventional, and temporal dimensions of practice", Sociological Research Online 10 (2).

Hards, S (2013) "Status, Stigma and Energy Practices in the Home”, Local Environment 18 (4): 438 -54 .

Hargreaves, T., Nye, M., and Burgess, J. (2010) "Making Energy Visible: a qualitative field study of how householders interact with feedback from smart energy meters", Energy Policy 38: 61116119.

Harvey, D. (2014) The Seventeen Contradictions and the End of Capitalism. London: Profile Books.

Hastings, A. (2004) "Stigma and Social Housing Estates: beyond pathological explanations", Journal of Housing and the Built Environment 19: 233-254.

HM Government (2010) Energy Bill: Green Deal Impact Assessment, from: http://www.decc.gov.uk/assets/decc/legislation/energybill/1002-energy-bill-2011-ia-green-deal.pdf

Kelly, S., Crawford-Brown, D., and Pollitt, M. G. (2012) "Building Performance Evaluation and Certification in the UK: is SAP fit for purpose?", Renewable and Sustainable Energy Reviews 16 (9): 6861-78.

Killip, G. (2013) "Products, Practices and Processes: exploring the innovation potential for low- 
carbon housing refurbishment among small and medium-sized enterprises (SME's) in the UK construction industry", Energy Policy, 62: 522-530.

Latiner, J (2015) "Linking Energy Efficiency to Economic Productivity: recommendations for improving the robustness of the US economy", Wiley Interdisciplinary Reviews: Energy and Environment, 4 (3):232-252.

Li, B. and Lim, D. (2013) "Occupant Behavior and Building Performance”, Design and Management of Sustainable Built Environments, Springer: 279-304.

Link, B.G. and Phelan, J.C. (2001) “Conceptualizing Stigma”, Annual Review of Sociology 27: 363385 .

Link, B, G. and Phelan, J, C. (2013) Stigma Power, Social Science and Medicine 103: 24-32

Lovell, H. (2004) "Framing Sustainable Housing as a Solution to Climate Change", Journal of Environmental Policy and Planning 6(1): 35-55.

Lutzenhiser, L. (2014) “Through the Energy Efficiency Looking Glass: rethinking assumptions of human behaviour", Energy Research and Social Science 1:141-151

Mallaburn, P.S. and Eyre, N. (2014) "Lessons from Energy Efficiency Policy and Programmes in the UK from 1973 to 2013”, Energy Efficiency 7 (14): 23-41.

Manley, D.J., Ham, M. V., Bailey, N., Simpson, L. and Maclennan, D. (2013) Neighbourhood Effects or Neighbourhood Based Problems? A Policy Context. Springer Verlag

McIntyre, Z. and McKee, K (2012) "Creating Sustainable Communities through Tenure-Mix: the responsibilisation of marginal homeowners in Scotland", Special Issue: Sustaining Communities: being in/between place in the neoliberal era, Geojournal 77 (2): 235-247.

McIntyre, Z. and McKee, K. (2008) "Governance and Sustainability in Glasgow: connecting symbolic capital and housing consumption to regeneration", Area 40 (4): 481-490.

McKee, K. and Hoolachan, J. (2015) "Generation Rent: what are the challenges for housing policy in Scotland?". St Andrews: University of St Andrews, Centre for Housing Research:

http://ggsrv-cold.standrews.ac.uk/CHR/Uploads/Edit/file/Carnegie\%20Final\%20Report_June2015.pdf

McKee, K. (2011a) Glasgow and West of Scotland Forum of Housing Associations' Response to the Scottish Government's Regeneration Discussion Document: Building a Sustainable Future. Glasgow and St Andrews: GWSF and University of St Andrews:

http://gwsf.org.uk/uploads/GWSFregenmay2011webversion.pdf

McKee, K. (2011b) "Challenging the Norm? The 'Ethopolitics' of Low Cost Homeownership in Scotland”, Urban Studies 48(16): 3399-3413.

McKee, K. (2009) "Post-Foucauldian Governmentality: what does it offer critical social policy analysis?" Critical Social Policy 29(3): 465-486.

Middlemiss, L., and Gillard, R (2015) "Fuel Poverty from the Bottom-up: characterising household energy vulnerability through the lived experience of the fuel poor", Energy Research and Social Science, 6:146-154

Parkhill, K; Butler, C; and Pidgeon, N.F. (2013) "Landscapes of Threat? Exploring Discourses of 
Stigma around Large Energy Developments", Landscape Research: 1-17

Pelenur, M., and Cruickshank, H (2012) "Closing the Energy Efficiency Gap: a study linking demographics with barriers to adopting energy efficiency measures in the home", Energy 47:348-357.

Priemus, H. (2005) "How to Make Housing sustainable? The Dutch experience" Environment and Planning B: Planning and Design 32 (1):5 - 19.

Ravetz, J. (2008) "State of the Stock - what do we know about existing buildings and their future prospects?" Energy Policy, 36: 4462-4470.

Rose, N. (2001) "Community, Citizenship, and the Third Way" in D. Meredyth and J. Minson (eds.), Citizenship and Cultural Policy. London: Sage.

Rosenow, J., Platt, R., and Demurtas, A. (2014) "Fiscal Impacts of Energy Efficiency Programmesthe example of solid wall insulation investment in the UK", Energy Policy, 74: 610-620.

Rowlands, R. and Gurney, C. (2001) "Young Peoples' Perceptions of Housing Tenure: a case study in the socialization of tenure prejudice", Housing Theory and Society 17: 121-130.

Scottish Household Survey (2013) http://www.scotland.gov.uk/Resource/0043/00439879.pdf

Scott, F., Jones, C., Webb, T. (2014) "What do People Living in Deprived Communities in the UK think about Household Energy Efficiency Interventions?” Energy Policy 66: 335-349.

Shirani, F., Butler, C., Henwood, K., Parkhill, K., and Pidgeon, N (2015) "I'm not a tree hugger, I'm just like you': changing perceptions of sustainable lifestyles, Environmental Politics, 24 (2): 57-74.

Slater, T. (2014) “"The Myth of 'Broken Britain': welfare reform and the production of ignorance”, Antipode 46(4): 948-969.

Shove, E (2003) Comfort, Cleanliness and Convenience: the Social Organsation of Normality. Berg: Oxford.

Shove, E. and Walker, G., (2014) "What is Energy For? Social Practice and Energy Demand", Theory, Culture and Design 31 (5): 41-58.

Spence, A., Demski, C., Butler, C., Parkhill, K., and Pidgeon, N. (2015) "Public Perceptions of Demand-side Management and a Smarter Energy Future", Nature Climate Change 5:550-554.

Sovacool, B. (2014) "Defining, Measuring and Tackling Energy Poverty", pp.21-53. In A. Halff, B. Sovacool, and J. Rozhon (eds.) Energy Poverty: global challenges and local solutions. Oxford: Oxford University Press.

Telfer, R.G.J. (1984) “Energy Conservation”, Electronics and Power 30 (8): 600-604.

Wacquant, L. (2008) Urban Outcasts: a comparative sociology of advanced marginality. Cambridge: Polity Press.

Wacquant, L (2009) Punishing the Poor. The Neoliberal Governance of Social Insecurity. Polity Press: Cambridge

Walker, G., and Day, R (2012) "Fuel Poverty as Injustice: integrating distribution, recognition and procedure in the struggle for affordable warmth", Energy Policy 49:69-75. 
Walker, G. (2014) "Temporal Dynamics of Energy Demand: change, rhythm and synchronicity", Energy Research and Social Science 1:49-55.

Warde. A. (2005) "Consumption and Theories of Practice", Journal of Consumer Culture 5 (2): 131153.

While, A., Jonas, A., and Gibbs, D. (2010) "From Sustainable Development to Carbon Control: ecoState restructuring and the politics of urban and regional development", Transactions of the Institute of British Geographers 35 (1): 76-93.

Wilhite, H., Shove, E., Lutzenhiser, L., and Kempton, W. (2000) "The Legacy of Twenty Years of Energy Demand Management: we know more about individual behaviour but next to nothing about demand", Society, Behaviour and Climate Change 8:109-126.

Wilson, C., Crane, L., and Chryssochoidis, G. (2015) "Why do Homeowners Renovate Energy efficiently? Contrasting Perspectives and Implications for Policy" Energy Research and Social Science 7:12-22.

Zhou, P., Ang, B., Zhou, D. (2012) "Measuring Economy-wide Energy Efficiency Performance: a parametric frontier approach", Applied Energy 90 (1):196-200. 